\title{
Hyperrreality in Avatar Film as a Form of Hegemony, Domination, and Capi- talist Ideology in Facing Society 5.0
}

\author{
Kinanti Resmi Hayati ${ }^{*}$, Nadia Afdholy², Terra Bellatrix Aden Nashahta ${ }^{3}$ \\ 1Universitas Pembangunan Nasional "Veteran" Surabaya, East Java, Indonesia \\ ${ }^{2}$ Airlangga University, Surabaya, East Java, Indonesia \\ ${ }^{3}$ UNUSA, Surabaya, East Java, Indonesia
}

*Corresponding author:

E-mail:

kinantihayati.ti@upnjatim.ac.id

\begin{abstract}
Indonesia is a country with third world values, which in the context of international structure is called periphery. The flow of information from the central countries (especially America) has been moving rapidly to Indonesia, not only in the form of economic activities but also in culture. The spread of culture is felt especially with films and television media. Today's globalization enables the mass media industry to create a mass culture and deliver messages to the masses. Capitalist ideology perpetuates the power of the masses by uniforming and homogeneity of events (identical). The film presents a variety of images that provide a stronger illusion related to understanding reality. Generally, film and society are understood as something linear, in the sense that film always influences society based on the content of its mandate without ever having the opposite. Avatar is a fictional film that takes us on a vacation to a planet that seems so real, where natural resources have been overused for decades. Through the film Avatar, the occurrence of hegemony, domination, and capitalist ideology can be seen from the image deliberately done by producers to accompany the masses on a mass culture product. The contents of the media present simulacra, pseudo needs, and create a pseudo world (hyperreality).
\end{abstract}

Keywords: Society, culture, capitalism, hyperreality

\section{Introduction}

The film presents a variety of images that provide a stronger illusion related to understanding reality. Generally, film and society are understood as something linear, in the sense that film always influences society based on the content of its mandate without ever having the opposite (Ritzer, 2006). Now various films with various genres can be seen increasingly flooding the market by coming together at the same time with its various influences. One that attracts attention is the film Avatar. Avatar is a 3D format science fiction film directed by James Cameron and won the 67th Globe award. The film produced by the 20th Century was released at the end of 2009 throughout the world. Avatar invites us on a vacation to a planet that looks so real, and after we finish watching we will be aware and a little sorry that we are not Na'vi people.

The film Avatar tells a story that began in the future, namely in 2154 where natural resources have been overused for decades. When natural resources began to run low, earth's inhabitants sought alternative energy sources by attacking and conquering Pandora, a planet in the solar system that was almost similar to Earth. Pandora is inhabited by primitive people who are very fanatical about ancestral spirits, shaped like a human, blue-skinned with white dots on his face, large, about 3 meters tall and has a tail. They are called the Na'vi. Some creatures in Pandora look beautiful and some look scary. This place has rare minerals (Unobtainium) in large quantities. This Unobtainium can produce magnets to make earth ships with extraordinary power. This is what

\section{How to cite:}

Hayati, K. R., Adholy, N., \& Nashahta, T. B. A. (2020). Hyperreality in avatar film as a form of hefemony, domination, and capatalist ideology in facing society 5.0. $1^{\text {st }}$ International Conference Eco. Innovation in Science, Engineering, and Technology. NST Proceedings. pages 233-237. doi: 10.11594/ nstp.2020.0537 
invites humans to conquer Pandora. The problem is that the seeds of Unobtainium are right under the ancestral spirit tree which is believed to be the most sacred place in Pandora.

The attack began when the inhabitants of the earth sent armed forces to conquer the Na'vi. Because humans cannot survive on Pandora, humans outsmarted them by creating creatures similar to Na'vi through scientific projects involving world scientists. The program is called "Avatar". The Avatar Jake Sully (Sam Worthington) a paralyzed former Marine was sent to Pandora. With this "Avatar" program, he can walk as usual. Its mission is to infiltrate the Na'vi for the sake of Unobtainium. The first journey to the unseen forest begins and almost attacks by strange creatures take his life. Luckily Neytiri (voice actor: Zoe Saldana) immediately came to save Jake. It was from Neytiri who turned out to be the daughter of a chief of the Pandora ruling tribe that Jake got information about Na'vi. Initially, Jake's presence did not get good reception, because most earth creatures who came to Pandora "had a wish". But then Neytiri's father was kind to Jake by assigning his son to teach the life of the Na'vi people, how to shoot, how to survive, and so on. Over time, Jake fell in love with Pandora, even he was involved in an affair with Neytiri. It was this love that made Jake the dilemma between defending the Na'vi or continuing the Pandora exploration mission. Finally, he chose to be a traitor to the nation and help the Na'vi defend Pandora. Then how can this reality be captured using the concept of hyperreality glasses?

\section{Research Method}

According to Alex Sobur, the media (press) is often referred to by many as the fourth estate (social power) in social, economic, and political life. This is mainly due to a perception of the role that can be played by the media about the development of the socio-economic and political life of the community. The media, especially in its position as an information institution, can also be seen as the most decisive factor in the processes of socio-cultural and political change. Therefore, in the context of mass media as an information institution, Karl Deutsch, called it the "nerve of the government" (the nerves of government).

Alex Sobur defines mass media as: "A tool to convey news, judgment, or a general picture of many things, he can act as an institution that can shape public opinion, among others, because the media can also develop into a pressure group on an idea or ideas, and even an interest or image that he represents to be put in a more empirical context of life. " Based on the definition of mass media according to Alex Sobur, it can be understood that mass media is a tool used to spread public opinion (public opinion) from dominant parties, such as the government. Usually, the dominant group uses mass media to construct reality which results to legitimize society towards a discourse.

Louis Althusser wrote that "The media, about power, occupies a strategic position, mainly because of their perceived ability as a suggestion of legitimacy. The mass media as educational institutions, religion, arts, and culture, are part of the tools of state power that work ideologically to build audience compliance with the ruling group (ideological states apparatus). " However, $\mathrm{Al}$ thusser's view of the media is considered Antonio Gramsci, in Al-Zastrouw, ignoring the ideological resistance of the subordinated class in the media space. For Gramsci, the media is an arena of competing for antarideological competing (the battleground for competing ideologies).

Antonio Gramsci in Alex Sobur sees, "Media is a space where various ideologies are represented. This means, on the one hand, the media can be a means of spreading the ideology of the authorities, a tool of legitimacy, and control over public discourse. But on the other hand, the media can also be a tool of resistance to power. The media can be a tool to build a dominant culture and ideology for the interests of the dominant class, as well as an instrument of struggle for the oppressed to build a counter-culture and ideology. "

From all the descriptions of the mass media, it can be concluded, the mass media is a tool or a means of spreading the ideology of dominant groups, a tool of legitimacy, and a tool of social control over public discourse. So it does not rule out the possibility of discursive practices by the media against marginal groups, which are suppressed by the dominant group (the ruler). This discursive practice can be used by the media as a means of legitimacy or justification for a problem 
context that is not following the dominant ideology. Alex Sobur argues that media content is essentially the result of the construction of reality with language as its basic tool. Likewise print media, print media content using text and language.

\section{Result and Discussion Hiperrealitas}

Jean Baudrillard, a well-known sociologist from France, in his book "Simulacra and Simulation", states that hyperreality is a concept in which reality in its construction cannot be separated from the production and play of signs that go beyond the original reality (hyper-sign). Hyperreality is a state in which falsity blends with authenticity, mixed. The past is mixed with the present, facts are confused with engineering, signs are fused with reality, lies are fused with the truth. Hyperreality presents reality models as a simulation (imitation similar to the original). The simulation creates a simulacrum (plural: simulacra), defined as an image or representation. Hyperreality makes people end up stuck on simulacra, and not on something real.

In this brief presentation, the writer tries to assemble the entire contents of the writing by using the concept of Hyperreality. Umberto Eco's thought in Travels in Hyper-reality (1986) for example, explains that hyperreality is all things that are replications of the elements of the past that are presented by the present context as if it were a nostalgia. So that when the past is presented in the context of the present time, it loses contact with reality, with the understanding of the past that can seem as if it is more real than the reality that is copied, thus creating a condition for the fusion of copies and originals (Eco, 1986: 43-48). In the phenomenon of hyperreality, there are still principles of representation. Imitation produced is still a representation of previous references. Meanwhile, Jean Baudrillard defines hyperreality as something that does not duplicate something else as a reference model but duplicates itself, in this case, the copy and the original are the same objects.

In this brief presentation, the writer tries to assemble the entire contents of the writing by using the concept of Hyperreality. Umberto Eco's thought in Travels in Hyper-reality (1986) for example, explains that hyperreality is all things that are replications of the elements of the past that are presented by the present context as if it were a nostalgia. So that when the past is presented in the context of the present time, it loses contact with reality, with the understanding of the past that can seem as if it is more real than the reality that is copied, thus creating a condition for the fusion of copies and originals (Eco, 1986). In the phenomenon of hyperreality, there are still principles of representation. Imitation produced is still a representation of previous references. Meanwhile, Jean Baudrillard defines hyperreality as something that does not duplicate something else as a reference model but duplicates itself, in this case, the copy and the original are the same objects.

Baudrillard's thoughts about the world of simulation and ideas about the phenomenon of hyperreality can be explained clearly and become easily understood through film, television, and video games (Baudrillard, 1987). In television discourse, films and video games follow Baudrillard's struggle with various elements: fiction and facts, reality and illusion, truth and falsehood, which are engineered, simulated so that they appear to be real. The reality in film, for example, becomes simulated reality: artificial reality is produced through the process of production and reproduction of various elements so that it is no longer possible to know which is original and which are false. Baudrillard sees that all this is just the mystification that capitalists are cramming for production and consumption. The real truth, that television audience choice and autonomy is nothing more than artificial choice. Autonomy is limited and regulated by existing choices (Baudrillard, 1987).

\section{Hyperreality as a form of hegemony, domination, and capitalist ideology}


Indonesia is a country with third world values, which in the context of international structure is called periphery. The flow of information from the central countries (especially America) has been moving rapidly to Indonesia, not only in the form of economic activities but also in culture. The spread of culture is felt especially with films and television media. This affects the culture that is accepted by the public through mass media such as television, film, print media, a radio which more or less can potentially change people's behavior and perception of value or culture that has been held firmly (Ibrahim \& Subandy, 1997).

Avatar is a film that tells about a satellite as big as the earth inhabited by the Na'vi whose civilization began to be disturbed by humans. The Na'vi are primitive creatures who at a glance resemble humans, only they are large, blue, and have tails. Avatar is a creature creation program that is similar to the Na'vi tribes so that it allows Jake to be able to walk again. While studying the life of the Na'vi, Jake discovered a variety of amazing things both from the culture of the Na'vi nation itself and from the beauty of the Pandora forest. "Avatar," tells of the war for survival between the Na'vi who lived in the forest, against colonial mining operations on their planet. Being stuck between two warring sides is never fun and that is what Jake Sully (Sam Worthington) experienced when he agreed to be sent to Pandora. On this alien planet inhabited by various creatures, Jake, who had hoped to start a new life, was involved in a complicated problem that required choosing parties. Jake is a former Marine who suffered severe injuries in a battle on earth. As a result, Jake's legs suffered total paralysis. There is one hope for Jake. If he follows the Avatar program and is sent to the planet Pandora, he will be able to walk again as before despite the consequences, Jake will use a 'new body'. To make it possible for humans to live on Pandora they were made an artificial body and the minds of these humans will be implanted into this body called an Avatar so that these Avatars are their bodies. Jake's job is to become a guide for some humans who use Avatar's body to find new mineral sources for industrial interests on earth. Along the way, Jake meets Neytiri (Zoe Saldana), the Na'vi inhabitants of the planet Pandora. Over time Jake fell in love with Neytiri. Starting from this love Jake then faced a dilemma between continuing his mission to explore Pandora or defend the Na'vi to protect Pandora.

The above process leads to the creation of simulacra (reproduction of objects or events). With the blurring of the difference between signs and reality, it becomes increasingly difficult to recognize the true nature of imitation goods (Lechte, 2001). Society becomes a simulation slave, "which forms an endless circle system. The film Avatar presented plays a dominant role to thrash the audience blue with the special effects presented. When related to the Baudrillard concept, this is what is meant by pseudo-reality (hyperreality), there is no longer any reality that exists only hyperreality. The impact resulting from hyperreality is the existence of people's trust in reality which is not reality. This duping of reality can produce cultural patterns that are easily imitated (imitations) of what they see as reality realized in daily life which then forms a mindset that is instantaneous, shapes humans who everything wants to be quickly available.

Referring to Luhan and Gramsci's concept of ideology, hegemony, and domination, mass media is a tool used by the ruling elites to preserve their power, wealth, and status by popularizing their philosophy, culture, and morality. In this case in line with that, the film making process also refers to the same thing, the existence of ideological elements, hegemony, and dominance of the owners and managers of the media industry in controlling and controlling other social groups and subtle coercion of their culture against other social groups by producing and reproducing content, and the tone of ideas that benefit them far more easily through the means of persuasion on the pretext of meeting their needs with concepts based on the consideration of dominant social groups (Eriyanto, 2011). Slowly but surely, the audience fell asleep with all the conveniences of life, a culture of instant consumption makes them forget that the life they face is starting to blur and sink into pseudo-reality.

In Indonesia, at this time the film is dominated by western films including the simultaneous display of Avatar in the country. This is inseparable from the capitalist system that hit the film industry when Indonesia entered the global current. In conditions like this, it is easy for other 
nations to penetrate the cultural and ideological hegemony of the Indonesian state. This is suspected one of them with the mastery of the Indonesian film system by western film supplier countries. It is easy for them to dictate according to their wishes and tastes, the taste of global capitalist ideology. A crisis of national character identity is not impossible at the moment in Indonesia. Indonesia is experiencing a current dilemma and value crisis. Film as a form of entertainment provider is indeed effective to eliminate all the fatigue of life, but the film can also be a marker of a nation's value crisis.

\section{Conclusion}

Referring to McLuhan and Antonio Gramsci's concepts of ideology, hegemony, and domination, mass media are tools used by the ruling elites to preserve their power, wealth, and status by popularizing their philosophy, culture, and morality. Today's globalization enables the mass media industry to create a mass culture and deliver messages to the masses. Mass culture generally only accommodates the low taste of mass society. Capitalist ideology perpetuates the power of the masses by uniforming and homogeneity of events (identical). Finally, mass culture only accommodates the low taste of mass society. Film as part of mass media and mass cultural products has a strong influence on giving birth to a passive society. Through the film Avatar, the occurrence of hegemony, domination, and capitalist ideology can be seen from the image deliberately done by producers to accompany the masses on a mass culture product. The contents of the media present simulacra, pseudo needs, and create a pseudo world (hyperreality).

\section{Acknowledgment}

The authors would like to thank all related parties that support the implementation of this research so that can be completed properly.

\section{References}

Baudrillard, J. (1988). Simulacra and Simulations. Stanford; Stanford University Press Eriyanto (2001). Analisis Wacana: Pengantara Analisis Teks Media. Yogyakarta: LKiS.

Ibrahim \& Subandy, I. (1997). Lifestyle Ectasy: Kebudayaan Pop dalam Masyarakat Komunitas Indonesia. Yogyakarta: Jalasutra. Lechte, J. (2001). 50 Filsuf Kontemporer: Dari Strukturalisme sampai Postmodernitas. Yogyakarta: Kanisius. Ritzer, G. (2006). Mengkonsumsi mediaKehampaan di Era Globalisasi. Yogyakarta: Universitas Atmajaya. 